\title{
Implementasi Kahoot dalam Pembelajaran Bahasa Prancis pada Masa Pandemi Covid-19 di SMK DKI Jakarta
}

\author{
Sri Harini Ekowati*1, Wahyu Tri Widyastuti², Asti Purbarini ${ }^{3}$ \\ 1,2,3Program Studi Pendidikan Bahasa Prancis, Fakultas Bahasa dan Seni, Universitas Negeri Jakarta \\ e-mail: sriharini@unj.ac.id ${ }^{1}$, wahyutri@unj.ac.id ${ }^{2}$, $^{\text {astipurbarini@unj.ac.id }}{ }^{3}$
}

\begin{abstract}
The information technology in learning during this pandemic situation is very important, because we did online courses, while not all teachers, including French teachers, are ready to do online courses. In learning stage there are preliminary, core and closing stages. In the preliminary stage contains information about Core Competencies (KI) and Basic Competencies (KD) that will be discussed, motivating students, apperception, etc. The core activity stage is the stage of making students understand the material in various ways and various media. The closing stage is to provide an evaluation, exercise, or test. This research focuses on the closing stage, which using Kahoot in the evaluation stage. Because not all French teachers know about Kahoot, this Kahoot implementation training becomes needed. The results are Kahoot documents made by French vocational schoolteachers. Kahoot is made according to their needs. There are 8 Kahoot documents with various KI and $K D$.
\end{abstract}

Keywords: Kahoot, French learning, Online course

\begin{abstract}
Abstrak
Penggunaan teknologi informasi dalam pembelajaran di masa pandemi ini menjadi sangat penting, karena pembelajaran saat ini dilakukan secara daring, sementara itu tidak semua guru, termasuk guru Bahasa Prancis siap untuk melakukan pembelajaran daring. Dalam tahapan pembelajaran terdapat tahap pendahuluan, inti dan penutup. Dalam tahap pendahuluan berisi informasi mengenai KI dan KD yang akan dibahas, memotivasi siswa, apersepsi, dsb. Tahap kegiatan inti adalah tahapan membuat siswa paham materi dengan berbagai cara dan berbagai media. Tahap penutup adalah memberikan evaluasi atau Latihan ataupun tes. Penelitian ini berfokus pada tahap penutup yaitu tahap evaluasi dengan menggunakan Kahoot. Karena tidak semua guru Bahasa Prancis mengenal Kahoot, maka pelatihan implementasi Kahoot ini perlu dilakukan. Hasil kegiatan ini adalah dokumen Kahoot yang dibuat oleh guru Bahasa Prancis SMK. Kahoot tersebut dibuat sesuai dengan kebutuhan mereka. Terdapat 8 dokumen Kahoot dengan berbagai KI dan KD.
\end{abstract}

Kata kunci: Kahoot, Pembelajaran Bahasa Prancis, Pembelajaran Daring

\section{PENDAHULUAN}

Pada masa pandemik Covid-19 yang dimulai sekitar Februari 2020, menyebabkan perubahan besar di segala bidang termasuk bidang pendidikan dan pengajaran. Pembelajaran yang biasanya berlangsung di kelas dan kita dapat bertemu, bertatap muka dan berinteraksi dengan siswa tidak dapat lagi dilakukan karena adanya aturan untuk menjaga jarak sosial di masyarakat. Pembelajaran tidak lagi dilakukan secara langsung di kelas, akan tetapi belajar di rumah masing-masing dan menggunakan sarana internet atau daring. Pembelajaran berubah menjadi PJJ (Pembelajaran Jarak Jauh). Perubahan yang tiba-tiba dan tanpa persiapan ini mengharuskan guru untuk mengajar via daring dengan memanfaatkan platform yang tersedia di internet. Ada banyak platform yang dapat digunakan oleh guru seperti Zoom Meeting, Google Classroom, Webex, Kahoot, Quizlet, dsb.

Awal tahun ajaran baru, Juli 2020 siswa mulai bersekolah lagi melalui PJJ, berarti pembelajaran daring akan berlangsung $100 \%$. Bagaimana menyiapkan materi pelajaran daring? Mengingat sebelum pandemik pembelajaran bersifat luring. Karena pembelajaran daring ini dilakukan secara tiba-tiba, tentu persiapan dan pengalaman yang dimiliki pengajar masih belum mencukupi.

Padahal untuk mengajar mata pelajaran secara daring, diperlukan persiapan yang memadai. Hal ini sesuai dengan penelitian yang dilakukan oleh Ilmiyah et al (2018) yang 
menyatakan bahwa jika guru akan menggunakan Kahoot maka ia harus membuat persiapan dengan cara membuka link http://create.kahoot.it. Melalui laman tersebut guru dapat membuat quiz dengan jumlah soal sesuai dengan kebutuhan. Ketika akan memulai quiz, akan didapatkan PIN yang menghubungkan siswa dengan quiz yang dibuat oleh guru.

Sejalan dengan artikel tersebut Rafnis (2018) mengatakan pembelajaran menggunakan aplikasi Kahoot membutuhkan piranti jaringan internet, komputer, infocus dan smartphone. Jika sekolah tidak memiliki perangkat tersebut, maka Kahoot tidak dapat diimplementasikan di kelas.

Berdasarkan hal-hal tersebut, maka ketika guru akan melakukan pembelajaran daring sebaiknya mereka mempersiapkan diri dengan persiapan-persiapan yang bersifat teknis yaitu yang berhubungan dengan cara-cara mengoperasikan platform dan juga persiapan yang berhubungan dnegan KI-KD, materi, dan hal-hal yang akan dievaluasi.

Sehubungan dengan cara-cara mengoperasikan Kahoot, berikut ini penjelasan dari Rofiyarti et al (2017) tentang cara menggunakan Kahoot untuk pembelajaran di kelas:

1. Pengajar mengakses website https://kahoot.com dan membuat akun;

2. Pengajar memilih atau membuat materi yang sesuai dengan umur dan kebutuhan anak dengan fitur yang sudah tersedia;

3. Pengajar membagi kelas dalam beberapa kelompok dan membekali kelompok tersebut dengan satu perangkat (handphone) dan mengakses https://kahoot.it;

4. Setelah dipilih atau dibuat materi yang sesuai, pertanyaan berupa pilihan ganda akan ditampilkan pada perangkat utama milik pengajar;

5. Pembelajar memilih jawaban yang sesuai.

Walaupun guru harus menyiapkan banyak hal sebelum menggunakan Kahoot, tetapi manfaat yang diperoleh melalui implementasi Kahoot cukup signifikan. Setiawati et al (2018) menyimpulkan bahwa hasil belajar kelompok siswa yang diajar dengan menggunkan media pembelajaran Kahoot lebih tinggi dari pada yang diajar tanpa Kahoot (Metode Konvensional).

Penelitian yang dilakukan oleh Licorish et al (2017) menyebutkan bahwa overall findings reveal that the deployment of Kahoot! enriches the quality of student learning in the classroom, with the highest influence reported on classroom dynamics, engagement, motivation, and improved learning experience yang berarti pembelajaran menggunakan Kahoot dapat meningkatkan kualitas belajar di kelas, menjadikan kelas lebih dinamis, memotivasi dan menumbuhkan pengalaman belajar.

Sejalan dengan penelitian tersebut Ismail et al (2017) menyatakan bahwa Kahoot is a promising formative assessment tool that is feasible, practical and makes learning fun and enjoyable. It can be used to motivate students to learn yang berarti Kahoot merupakan alat penilaian formatif yang layak, praktis dan membuat belajar menjadi menyenangkan. Kahoot dapat digunakan untuk memotivasi siswa belajar.

Dari penelitian-penelitian yang dilakukan dapat dilihat bahwa Kahoot memiliki dampak positif dalam pembelajaran. Untuk itu guru pun harus memiliki kesiapan untuk dapat mengoperasikan Kahoot agar dapat diimplementasikan dengan baik di kelas. Mengingat bahwa mangajar daring perlu banyak persiapan dan mengingat guru-guru Bahasa Prancis SMK di DKI Jakarta yang tidak semuanya menguasai Teknologi Informasi dan Komunikasi (TIK) maka tim P2M Prodi Pendididikan Bahasa Prancis UNJ mengadakan pelatihan tentang merancang dan mengimplementasikan Kahoot di kelas masing-masing. Pelatihan ini memberi banyak manfaat bagi para guru Bahasa Prancis SMK di DKI Jakarta, yaitu menambah wawasan, meningkatkan skill (kemampuan dalam memanfaatkan TIK), meluaskan jejaring, dsb.

Hal ini sesuai dengan artikel dalam http://www.ruangmahasiswa.com yang menyatakan bahwa paling tidak ada 7 manfaat mengikuti pelatihan, yaitu: 1) menambah dan mengembangkan wawasan, 2) mengembangkan hard skill, 3) mengetahui kesalahan elementer (dasar) atas 
pemahaman kita, 4) belajar dari orang hebat, 5) mengajari kita rendah hati, 6) modal kerja, dan 7) menambah jejaring.

Artikel lain yang membahas mengenai manfaat pelatihan adalah pelatihan yang dilaksanakan UPTD LLK-UKM di Mempawah oleh Apriani et al (2017), mereka menyimpulkan bahwa manfaat pelatihan adalah dapat meningkatkan kemampuan berpikir, kemampuan bekerjasama, kemampuan dalam menumbuhkan minat dan kemampuan mengembangkan.

Penelitian yang dilakukan oleh Engetau (2017) menyatakan bahwa the research also reveals that training and development is a necessity in every companies particularly for the unskilled or the less experience employees. Generally, employees' work contribution was greatly improved due to the training methods and tools used by the company. Thus, it led to a positive impact on employee' performance and an improvement in their skills and job efficiency yang dapat disimpulkan bahwa pelatihan merupakan suatu keharusan karena dapat memberikan dampak positif pada peningkatan kinerja dan keterampilan serta efisiensi kinerja.

Dari penelitian-penelitian yang telah dilakukan oleh para peneliti membuktikan bahwa pelatihan-pelatihan yang diselenggarakan memberikan banyak manfaat bagi pesertanya. Manfaat yang diperoleh tidak hanya manfaat profesional tetapi juga personal. Pelatihan dapat meningkatkan karir seseorang sekaligus dapat mengembangkan aspek sosial seperti pertemanan, jejaring sosial, dsb. Berdasarkan temuan-temuan penelitian tersebut di atas maka tim P2M Prodi Pendidikan Bahasa Prancis, Universitas Negeri Jakarta memutuskan untuk mengadakan pelatihan pembuatan Kahoot sebagai sarana untuk evaluasi di kelas dan bagaimana mengimplementasikan di kelas.

\section{METODE}

Kegiatan ini dilakukan dalam bentuk pelatihan pembuatan Kahoot dan implementasinya di kelas. Pelatihan berlangsung selama 12 jam. Setiap pertemuan berlangsung 4 jam via Zoom Meeting dengan rincian 2 jam daring dan 2 jam luring. Pertemuan berlangsung sebanyak 3 kali. Pelatihan ini diikuti oleh 15 guru Bahasa Prancis dari berbagai SMK di DKI Jakarta. Mereka berasal dari SMKN 30, SMK Angkasa, SMKN 57, SMK Cipta Karya, SMK 28 Oktober, SMK Harapan Bunda, dsb.

Pertemuan pertama adalah perkenalan, saling memperkenalkan diri, kemudian paparan mengenai tujuan pelatihan yang disampaikan oleh ketua tim P2M Prodi Pendidikan Bahasa Prancis, sambutan dari MGMP Bahasa Prancis SMK DKI Jakarta dan kemudian Pelatihan.

Dimulai dengan pemberian pre-tes yang bertujuan untuk mengetahui kemampuan awal guru-guru dalam hal teknologi informasi dan komunikasi, bagaimana posisi guru ketika mengimplementasikan TIK dalam pembelajaran di kelas. Setelah peserta mengisi angket, kemudian disampaikan paparan mengenai Kahoot. Berikut ini adalah materi pelatihan yang dirangkum dari http://www.kahoot.com :

Apa itu Kahoot?

Kahoot merupakan platform permainan pembelajaran yang memanfaatkan Teknologi dan Informasi. Dengan menggunakan Kahoot pembelajaran dapat dilaksanakan secara menyenangkan melalui permainan. Kahoot dapat digunakan dimana saja dan kapan saja asalkan memiliki jaringan internet dan gawai seperti laptop atau smartphone. Permainan pembelajaran Kahoot berupa Quiz pilihan ganda yang dibuat oleh guru dan dapat dijawab secara interaktif oleh siswa melalui web atau aplikasi Kahoot.

Bagaimana cara menggunakan Kahoot?

1. Guru mengakses www.kahoot.com pada browser, lalu klik Sign Up untuk membuat akun baru atau Log In apabila sudah memiliki akun. 


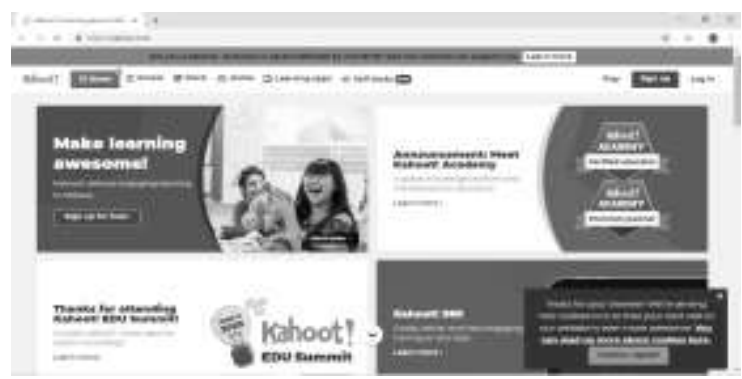

Gambar 1. Halaman Muka Kahoot

2. Guru mengisi email dan password atau dapat memilih untuk menggunakan akun Google, Microsoft atau Apple.

Bagaimana membuat Quiz Kahoot?

1. Setelah guru Sign Up atau Log In, maka tampilan Kahoot akan terlihat seperti gambar di bawah:

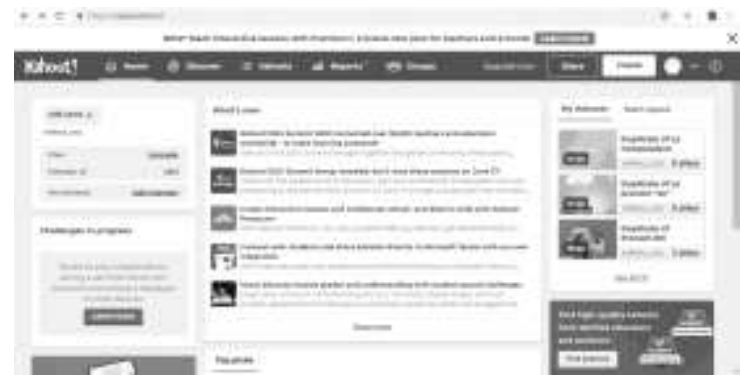

Gambar 2. Halaman Muka Log In

2. Untuk membuat Quiz baru, klik Create, lalu klik New Kahoot. Guru dapat membuat Quiz sesuai kebutuhannya dengan menggunakan menu-menu yang telah tersedia. Guru dapat menyisipkan teks, gambar atau video Youtube.

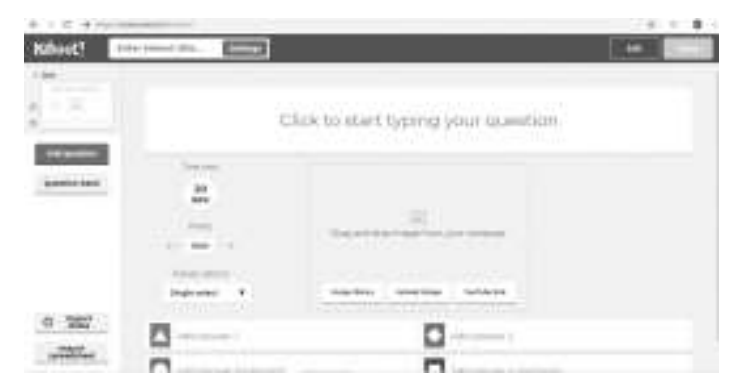

Gambar 3. Halaman New Kahoot

3. Selain membuat Quiz baru, guru juga dapat menggunakan Quiz yang sudah tersedia dengan cara klik Discover, lalu ketikkan materi yang dicari, contohnya 'les vetements'. Maka akan muncul beberapa Quiz, pilih sesuai kebutuhan dan klik Duplicate. Maka guru sudah dapat menggunakan Quiz tersebut tanpa harus membuat Quiz yang baru.

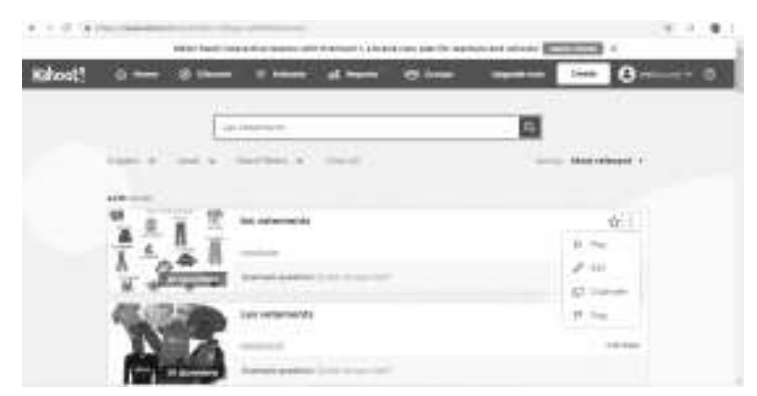

Gambar 4. Halaman Discover 
Apa yang harus disiapkan guru dan siswa?

1. Guru dapat melihat Quiz yang telah dibuat di menu My Kahoot. Pilih Quiz Kahoot yang akan digunakan untuk pembelajaran di kelas atau melalui virtual, lalu klik Play dan pilih Teach. Pilih Classic apabila guru ingin siswa bekerja secara individua atau Team Mode apabila ingin siswa bekerja secara kelompok. Maka akan muncul PIN yang harus diisikan siswa untuk dapat bergabung dalam Quiz.

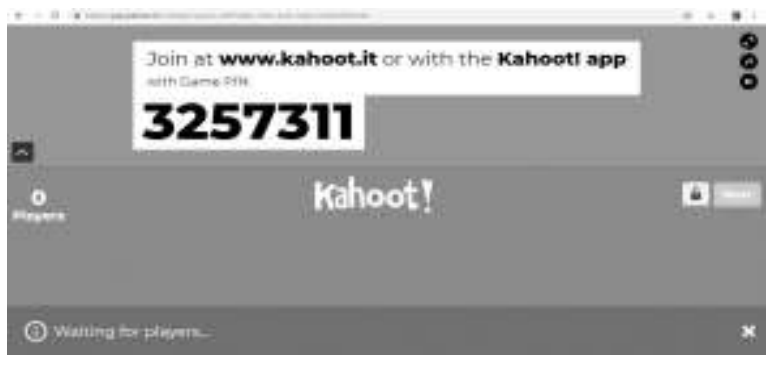

Gambar 5. Halaman PIN Quiz

2. Siswa mengakses Quiz melalui http://www.kahoot.it. Lalu memasukkan Game PIN, lalu Enter. Setelah bergabung maka Quiz dapat dimulai.

Setelah paparan selesai, selanjutnya adalah diskusi dan tanya jawab. Para peserta banyak mengajukan pertanyaan mengenai Kahoot ini. Setelah diskusi dilanjutkan dengan praktik. Masing-masing peserta membuka platform Kahoot, dengan bimbingan instruktur, lalu mereka praktik membuat Quiz Kahoot sesuai dengan kebutuhannya. Pelatihan membuat quiz bersifat luring, komunikasi dilakukan dengan WA Group selama 60 menit. Sesudah siap dengan tugas membuat Quiz, pelatihan berlangsung daring lagi. Peserta presentasi hasil pekerjaan membuat Quiz dengan Kahoot.

Pertemuan berikutnya via Zoom Meeting, pada dua jam pertama adalah lanjutan presentasi Quiz Kahoot yang dibuat oleh para peserta. Tanya jawab dan diskusi antara instruktur dengan peserta pelatihan serta diskusi antar peserta dilakukan untuk perbaikan Quiz yang mereka buat. Waktu yang tersedia selama 2 jam digunakan untuk presentasi 6 orang peserta. Dua jam berikutnya adalah presentasi dan diskusi 6 peserta berikutnya. Prosesnya sama dengan kegiatan di atas yaitu presentasi, tanya jawab, diskusi dan pemberian umpan balik oleh instruktur untuk perbaikan Quiznya.

Pertemuan ketiga (terakhir) berlangsung 4 jam. Pada 2 jam pertama, instruktur menentukan Quiz yang harus dibuat peserta adalah untuk siswa kelas XII. Kegiatan berlangsung via WA grup dan luring. Setelah para peserta siap dengan quiznya kemudian bertemu lagi via Zoom Meeting untuk mendiskusikan Quiz yang sudah dibuat. Diskusi berlangsung satu jam. Satu jam berikutnya digunakan untuk mengisi angket (post-test) mengenai pembelajaran/ evaluasi dengan Kahoot. Peserta mengungkapkan pesan dan kesan, komentar, kritik dan harapannya. Kegiatan ditutup dengan kata-kata penutup oleh Ketua Tim P2M Prodi Pendidikan Bahasa Prancis.

\section{HASIL DAN PEMBAHASAN}

Hasil kegiatan P2M ini adalah pemahaman peserta pelatihan terhadap Kahoot, dapat menyusun Quiz menggunakan platform Kahoot dan menerapkannya di kelas masing-masing. Hal tersebut sangat bermanfaat bagi peseta di masa pandemik Covid-19 ini, karena saat ini pembelajaran tidak berlangsung di kelas tetapi pembelajaran jarak jauh dan menggunakan internet, jadi belajar mengajar secara daring dengan menggunakan smartphone, komputer maupun komputer jinjing dengan fasilitas internet yang memadai.

Peserta pelatihan, yang kesemuanya guru Bahasa Prancis dapat memanfaatkan hasil pelatihan ini untuk keperluan pengajaran di kelas. Karena pembelajaran dengan Kahoot ini 
memanfaatkan TIK, maka pembelajaran akan menjadi lebih menarik bagi siswa. Seperti yang dinyatakan oleh Barus (2018) dalam artikelnya pada Prosiding Seminar Nasional Teknologi Terapan Berbasis Kearifan Lokal, yang menyimpulkan bahwa Kahoot itu menarik bagi siswa dan membantu meningkatkan minat dan motivasi belajar Bahasa Inggris.

Hasil post-test yang dilakukan menunjukkan bahwa para pesereta pelatihan memahami bahwa pembelajaran Bahasa Prancis yang berpusat pada siswa itu penting, bahwa penggunaan Teknologi Informasi dan Komunikasi itu perlu dilakukan di kelas, dan Kahoot merupakan salah satu yang direkomendasikan di kelas.

Sehubungan dengan kesan, saran dan masukan terhadap pelatihan yang dilakukan oleh tim P2M Prodi Pendidikan Bahasa Prancis, berikut ini beberapa saran yang mereka berikan:

Tabel 1. Saran Peserta Pelatihan

\begin{tabular}{cl}
\hline Inisial & \multicolumn{1}{c}{ Saran } \\
\hline TR & $\begin{array}{l}\text { Semoga ada pelatihan yang seperti ini lagi } \\
\text { AF }\end{array}$ \\
Semoga pelatihan seperti ini dpaat dilakukan lagi dan kami sebagai pengajar \\
dapat mengaplikasikan ilmu yang baru ini di kelas PJJ \\
Merci beaucoup et j'attends la suite formation (Terima kasih banyak, saya \\
pelatihan selanjutnya)
\end{tabular}

Kahoot yang dibuat oleh peserta pelatihan:

A. LEXICAL

1. Dans la maison

https://create.kahoot.it/details/la-maison/9c4c2f3b-9e83-4896-9390-102b4e2367f9

2. Les couleurs

https://create.kahoot.it/share/a11-0-les-couleurs/e7397d3c-536c-4d30-b86b-f797f

3. La famille

https://create.kahoot.it/share/la-famille/6748dc40-3e91-4a2b-af4e-a42851c8edb0

4. La chambre

https://create.kahoot.it/share/vocabulaire-dans-ma-chambre/1b32b7b4-5366-4518-

9c98- 864713546e02

5. Les chiffres

https://create.kahoot.it/share/le-chifre/9cad8336-980f-44a4-8fde-fc867d6e448a

6. Le voyage

https://create.kahoot.it/details/le-vocabulaire-du-voyage/2d11cbef-e52b-4a09-bf66$\underline{922 \mathrm{cb} 2185983}$

B. GRAMMATICAL

1. Réserver un hotel

https://create.kahoot.it/details/reserver-un-hotel-review/6604329a-a00d-4efc-83a0a436003610df

2. Dans un restaurant

https://create.kahoot.it/details/dans-un-restaurant/8af66d03-3f30-47f5-9353-

96a2fce98068 


\section{KESIMPULAN}

Berdasarkan paparan di atas, kesimpulannya adalah pelatihan tentang implementasi Kahoot di kelas Bahasa Prancis SMK di DKI Jakarta dapat dikatakan berhasil. Peserta pelatihan meningkat kemampuannya dalam hal pembuatan quiz dengan Kahoot, mereka juga merasakan kegunaan/ manfaat dari pelatihan singkat yang diberikan oleh tim P2M Prodi Pendidikan Bahasa Prancis UNJ.

Walaupun pelatihan ini berjalan dengan lancer dan baik, bukan berarti tidak ada kendalanya. Karena pelatihan ini bersifat daring yaitu dengan Zoom Meeting, maka persoalan sinyal, wifi dan kuota tetap menjadi kendala. Beberapa peserta tidak dapat bergabung tepat waktu karena sinyal yang buruk, jadi ada saja yang terlambat bergabung. Namun demikian karena pelatihan ini juga menyediakan Powerpoint dan juga dokumen tulis lain, maka peserta tetap dapat mengikuti melalui Powerpoint dan dokumen tulis.

\section{UCAPAN TERIMA KASIH}

Tim P2M Prodi Pendidikan Bahasa Prancis mengucapkan terima kasih kepada LPPM Universitas Negeri Jakarta yang telah memberikan dukungan finansial sehingga pelatihan dapat berjalan dengan baik dan lancar. Tim P2M menyampaikan pula rasa terima kasih kepada MGMP Bahasa Prancis Jakarta atas kerjasamanya dalam pelatihan ini.

\section{DAFTAR PUSTAKA}

Apriani, P., Matsum, J. H., Khosmas, F. Y. (2017). Analisis Manfaat Pelatihan yang Dilaksanakan UPTD LLK-UKM di Mempawah. Jurnal Pendidikan dan Pembelajaran Untan, 6(6), 1-11.

Barus, I. R. G., Soedewo, T. (2018). Penggunaan Media Kahoot! Dalam Pembelajaran Struktur Bahasa Inggris. Studi Kasus: Mahasiswa Sekolah Vokasi IPB. Prosiding Seminar Nasional Teknologi Terapan Berbasis Kearifan Lokal, 1(1), 589-596.

Engetou, E. (2017). The impact of training and development on organizational performance. University of Applied Science. Unduh 25 Juli 2020, dari https://journals.sagepub.com/doi/full/10.1177/2158244011433338

Ilmiyah, N. H., Sumbawati, M. S. (2019). Pengaruh Media Kahoot dan Motivasi Belajar Terhadap Hasil Belajar Siswa. Journal of Information Engineering and Education Technology, 3(1), 4650.

Ismail MA. A, Mohammad JA. M. (2017). Kahoot: a promising tool for formative assessment in medical education. Education in Medicine Journal, 9(2), 19-26.

Licorish, S. A., George, J.L., Owen H. E., Daniel, B. (2017). Go Kahoot! Enriching Classroom Engagement, Motivation and Learning Experience with Games. Proceedings of the 25th International Conference on Computers in Education. 755-764.

Rafnis. (2018). Pemanfaatan Platform Kahoot Sebagai Media Pembelajaran Interaktif. E-Tech Jurnal Ilmiah Teknologi Pendidikan, 6(2), 1-9.

Rofiyarti, F., Sari, A. Y. (2017). TIK Untuk AUD: Penggunaan Platform Kahoot! dalam Menumbuhkan Jiwa Kompetitif dan Kolaboratif Anak. Pedagogi: Jurnal Anak Usia Dini dan Pendidikan Anak Usia Dini, 3(3b), 164-172.

Setiawati, H. D., Sihkabuden, Adi, E. P. (2018). Pengaruh Kahoot Terhadap Hasil Belajar Siswa Kelas XI di SMAN 1 Blitar. Jurnal Kajian Teknologi Pendidikan. 1(4), 273-278.

Sobat RuangMahasiswa. (2017). 7 Manfaat Mengikuti Pelatihan. Unduh 15 Juli, 2020, dari http://ruangmahasiswa.com/info/7-manfaat-mengikuti-pelatihan 